\title{
CDE faces verification problems for chemical weapons
}

Porton Down, Wiltshire

SCIENTISTs from the UK Chemical Defence Establishment (CDE) who exchanged visits this year with staff from the equivalent Soviet facility at Shikhany, $600 \mathrm{~km}$ south-east of Moscow, were neither given access to a set of buildings that are clearly identifiable on satellite photographs, nor provided with satisfactory information about them, despite requests. They suspect the main building is a chemical production plant of some kind. In general, says CDE's director, Dr Graham Pearson, the Soviets have revealed very little of their developments in chemical weaponry over the past 30 years.

A major cause of concern is the possible development of chemicals that are closely related to biological agents but may not be covered by the ban imposed by the biological weapons convention of 1972 . The blurring of the distinction between chemi-

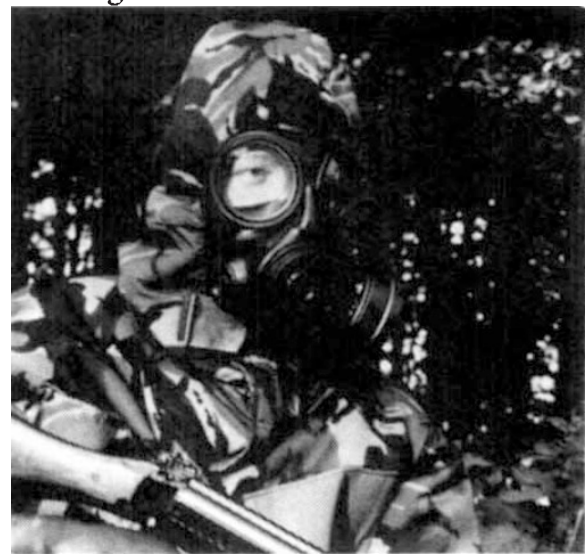

Cheers: the new "General Service Respirator" from Porton is the first to allow the wearer to drink safely in a contaminated environment.

cal and biological weapons is exacerbated by recombinant DNA technology. This would allow the production in quantity of versions of bacterial toxins and potentially toxic neuropeptides, such as Substance $\mathrm{P}$, that were sufficiently altered arguably to be classified as chemicals.

The possible production and deployment of new chemical agents is adding to the research load of the 400 staff at CDE, the Ministry of Defence establishment that claims to work solely on defensive and protective measures against chemical and biological weapons. Underlying their concern is the fact that many of the newer chemicals are so closely related to substances with a genuine industrial use that it would be easy to build a dual-production facility and disguise its second purpose.

That possibility is exercising the minds of those concerned with verification measures. A second verification problem is the identification of new or even classical chemical weapons in field samples. There is little doubt from firsthand descriptions that chemical weapons were used in Cambodia, says Pearson, but their identity is unknown.

For detection of chemical agents in the battlefield, CDE is developing secondgeneration ion mobility spectrometers. The most promising has two drift tubes sharing a common source region, which allows the simultaneous detection of positive and negative ions, but it will need considerable software development to enable such spectrometers to detect and give warning of the presence of any chemical weapon.

Other current research at CDE includes the improvement, by chemical modification, of the adsorption properties of the granular charcoal that is the main protective substance in gas masks and anti-gas

\section{Alvey programme under fire}

\section{London}

THE UK government's information technology programme, financed jointly with private industry and intended to rectify the serious adverse balance of trade in information technology products, was criticized last week in a report by the House of Commons Committee of Public Accounts. The $£ 350$-million five-year Alvey programme, which began in 1983 , suffered from understaffing and poor management, says the committee. Because three government departments were involved, there were problems of contracting, financial control and financial support.

Severe delays were caused because project participants found it difficult to secure collaboration; the Alvey directorate could have done more to help, says the committee. It also criticizes the decision to direct more money than planned into research in academic institutions, arguing that savings from carrying out research more cheaply in universities are outweighed by the loss of funds from industry.

Although the committee praises the directorate for instigating cooperation between academic institutions and industry, it says that there was much less participation than planned. And it says the project was affected by the country's skills shortages in information technology.

The first five years of the project were to have been followed by a second phase. But the programme will not now be continued; in future, the country's main information technology effort will be channelled through the European ESPRIT programme.

Christine McGourty fabric, and the development, in conjunction with Roche, of a soluble pro-drug form of diazepam, which combats the convulsive effects of nerve gases. The prodrug will be added to the other two soluble agents in the self-administration syringe currently supplied to UK forces along with a diazepam tablet. Another industrial collaborator is Celltech, the UK biotechnology company. Using the company's know-how in monoclonal-antibody-based diagnostics, CDE biologists have developed a 10-minute field-test for Clostridium perfringens phospholipase $\mathrm{C}$, the major toxin responsible for gas gangrene. They are also working on an improved vaccine against the bacterium.

There is a danger that the production of effective protection against existing chemical and biological weapons will encourage the development of new weapons, admits Pearson, which is why CDE "does not publish precise performance parameters of equipment".

Peter Newmark

\section{Lecturer resigns over MOD funding}

\section{London}

A GRANT of $£ 235,000$ from the Ministry of Defence (MOD) to the veterinary school of the University of Bristol has led to the resignation of at least one academic member of staff on the grounds that the work has links with biological warfare, although this is denied by the university.

The project at the centre of the debate is to be carried out in the department of animal husbandry and will concentrate on the study of the organism, Klebsiella pneumoniae, which those protesting against the grant say causes mortality in man, but is of no significance to animal respiratory disease. Dr Sue Mayer, who has resigned from her position as lecturer, says she cannot work there because she feels the improvement of animal health and welfare is a 'spin-off' rather than the principal justification of the work. Another member of staff is also said to have resigned.

But the grant-holder, the head of the department and the vice-chancellor of the university have no complaints about the funding of the project by the MOD and deny charges that it was redesigned to suit the MOD after the Agriculture and Food Research Council refused to support it.

The Association of University Teachers, which originally spoke out in support of those protesting at the grant, has rescinded that support and apologized to the university.

The start of the project has now been delayed; a spokesman for the university says that this is due to the reluctance of the MOD to pay overheads and certain expenses.
Christine McGourty 